\title{
The Physiological and the Social in the Psychologies of Dewey and Thorndike: The Matter of Habit
}

\author{
Timothy Koschmann, Dept. of Medical Education, Southern Illinois University \\ Tel: +1-217-785-4396, Fax: +1-217-524-0192 \\ Email: tkoschmann@acm.org
}

\begin{abstract}
This paper seeks to compare the psychologies of Thorndike and Dewey by focusing on their respective treatments of habit in human learning and behavior. The issue is of more than historic interest in that a focus on this aspect of their positions not only reveals much about the two and their contributions to current thought but also provides a point of perspective for a more general reappraisal of the foundations of the learning sciences today. Habits, for Thorndike, could be divided into the instinctive and the acquired. Within his psychology, both types of habits consisted of predispositions to respond in particular ways to particular stimuli. Habits were a primary concern for Dewey, as well. Most day-to-day conduct, he believed, is ruled by habit. When disrupted, however, conduct comes under the influence of impulse and intelligence. Dewey introduced the term inquiry for the process by which intelligence recovers a situation that has in some way become problematic. Dewey's call for the inclusion of "the social" in psychology, was a call for a totally new approach to research into human learning and interaction. The implications for future work in educational research of adopting Dewey's approach are discussed.
\end{abstract}

Keywords: social cognition, foundations, pragmatism, educational psychology

[A]ll psychological phenomena can be divided into the physiological and the social, and ... when we have relegated elementary sensation and appetite to the former head, all that is left of our mental life, our beliefs, ideas and desires, falls within the scope of social psychology. (Dewey, $1985 / 1917$, p. 54)

The epigraph comes from an address delivered by Dewey on the twenty-fifth anniversary of the American Psychological Association (APA). In it, Dewey argues for the inclusion of the social in psychological research. As examples of psychologists who had already made moves in this direction, he cited approvingly William James, the British psychologist McDougall, and his colleague at Columbia, E. L. Thorndike! Dewey goes on to applaud efforts by Thorndike and others to introduce statistical methods and behaviorism into the study of social aspects of cognition. Given contemporary perceptions of these two men and their respective bodies of work, this is, to say the least, an unexpected endorsement. Is it possible that Dewey and Thorndike actually held compatible views of the biological and social as they enter into learning?

Thorndike and Dewey did have a number of things in common. Both were from middle-class backgrounds and both entered college at a time in which graduate study at a European university was considered de riguier for anyone with aspirations of eventually teaching at a university. Thorndike and Dewey, however, were scholars of the homegrown variety-both products of the newly-developed graduate programs that had just been introduced at a small number of American research universities. Intellectually, both were deeply influenced by the philosopher and psychologist, William James. Thorndike began his graduate studies with James at Harvard, before moving to Columbia to complete his doctorate. Though he neither studied under nor worked directly with James, Dewey was profoundly influenced in his philosophical thinking by James' writings, to the extent that their names are frequently listed together (along with Peirce and Mead) as founders of American Pragmatism. Further, both Thorndike and Dewey wrote of education in what Lagemann (1989) termed the "progressive idiom" and both espoused an abiding faith in the power of science to improve educational practice. The two were colleagues at Columbia-Dewey in Philosophy, Thorndike at Teachers College-for thirty-five years. 
There were, of course, many differences as well. Though he dabbled a bit at experimental psychology while a graduate student at Johns Hopkins and later established a laboratory school in Chicago for the study of educational problems, by the time Dewey arrived at Columbia he had turned his full interests to the more abstract problems of academic philosophy. Thorndike, on the other hand, trained in experimental psychology, first with James at Harvard and later with Cattell at Columbia. Though his doctoral research was in comparative psychology, when he assumed his professional post at Teachers College, his interests broadened to include educational psychology, an area of inquiry he helped to establish and which he subsequently came to dominate. Indeed, Thorndike never developed a patience for, nor interest in, philosophical concerns - he was first, last, and foremost a designer of experiments and a compiler of data, the consummate experimentalist.

This paper seeks to compare the psychologies of Thorndike and Dewey by focusing on their respective treatments of habit. The issue is of more than historic interest in that a focus on this aspect of their positions not only reveals much about the two and their contributions to current thought but also provides a point of perspective for a more general reappraisal of the foundations of the learning sciences today. I begin then by summarizing the respective positions developed by the two writers.

\section{Thorndike's Legacy: Psychology as a Biological Account of Behavior}

We might do well to remember that James, Thorndike's advisor at Harvard and lifelong mentor, received his formal training in medicine and that a central thrust of the 'new psychology' was to put its study on a scientific (read biological) basis. Its precursors were recent developments in physiology on neural reflexes, Darwin's theory of natural selection, and the psychophysics work being done in the newly established psychology laboratories in Germany (Sahakian, 1975). Biology, as a result, was at the core of mainstream American psychology and Thorndike embraced and extended this tradition.

Habits, for Thorndike, could be divided into the instinctive and the acquired. Habits of the former type were of great importance to Thorndike. The first of his James lectures (1969/1943) at Harvard, delivered near the end of his career, was entitled, "The Original Nature of Man: The Genes of the Mind." Instinctual behavior for Thorndike was the result of genetic predispositions to respond to particular stimuli in particular ways. He wrote, "the original tendencies to response set up by the genes are all limited to situations presented to the senses or represented to imagination as a consequence of presentation to the senses" (p. 16-17). Instincts reflect the direct influence of natural selection on behavior.

Acquired habits are the additions and modifications to this "original gene-caused stock" (p. 22) of associations or, to use Thorndike's preferred term, "connections" between stimuli and responses. Acquired habits, like instincts, have a biological basis in Thorndike's writing. His fundamental Law of Effect that "those [responses] which are accompanied or closely followed by satisfaction to the animal will, other things being equal, be more firmly connected with the situation, so that, when it recurs, they will be more likely to recur" (Thorndike, 1911, p. 244) rests on a quasi-neurological model of learning. Thorndike, in fact, clearly believed that these "sarbons"1 had neural correlates. He (1913) wrote, "By original nature a certain situation starts a behavior-series: this involves not only actual conduction along certain neurons and across certain synapses, but also the readiness of others to conduct" (Vol. I, p. 126). Thorndike (1935) conceded, however, that "what happens in the neurons cannot in the present state of science be observed. The series of physiological events from the situation to the response is inaccessible" (p. 10).

Thorndike believed that the effects of experience on the organism could still be studied, however, by observing changes in behavior. He (1911) wrote, "if the same situation produces on two occasions two different responses, the animal must have changed" (p. 241). Thorndike thereby planted the seeds of the now thoroughly accepted notion that learning is to be studied and understood by measuring changes in behavior (e.g., improvement in performance, reduction in error rates). Learning, indeed, has become conceptually inseparable from the methods by which it is quantified. ${ }^{2}$ Hence, though he disdained consideration of matters philosophical, in his work and writing, Thorndike effected a thoroughgoing brand of positivism.

Thorndike argued that research on learning should start at the most elemental levels and build up. He (1913) wrote: 
These simple, semi-mechanical phenomena . . . which animal learning discloses, are the fundamentals of human learning also. They are, of course, much complicated in the more advanced states of human learning, such as acquisition of skill with the violin, or of knowledge of the calculus, or of inventiveness in engineering. But it is impossible to understand the subtler and more planful learning of cultural men without clear ideas of the forces which make learning possible in its first form of directly connecting some gross bodily response with a situation immediately present to the senses. (Vol. II, p. 16)

Thorndike applied this same strategy to inter-psychological phenomena as well.

When Thorndike became interested in issues related to language, as he did later in his career, he theorized that language had its origins in the acquisition of special S-R bonds associating a word with a meaning. His "babble-luck" theory of language ontogenesis posited that verbal symbols emerged from chance pairings of selfproduced random vocal behavior with particular acts and objects (Thorndike, 1969/1943). For Thorndike, therefore, language and other aspects of social behavior were constructed from (and understandable as) primitive associations of stimuli and responses, that is habits instinctive and acquired.

For this reason Thorndike viewed psychology as foundational to the social sciences. Early in his career (1904) he wrote, "psychology will undoubtedly assume the relation to the other sciences of human affairs which physics how holds to geology, meteorology, astronomy" (p. 324). He (1969/1940) later elaborated:

Psychology cannot as yet claim to be an adequate science of human thought, feeling, and action, upon which all the social sciences rest and with which they must agree . . But human biology and psychology make a substantial contribution. They settle questions outright and turn the balance for others. (p. v)

For Thorndike, therefore, there was but one learning science and it was psychology with its putative basis in biology.

Thorndike's legacy to psychological theorizing and educational research is evident all around us. The everpopular drill-and-practice methods of teaching are nothing more than applications of Thorndike's Laws of Exercise and Effect. The strategy of teaching via decomposition of complex subject matter to its most elemental components, a standard theme in Thorndike's work, is the basis for today's instructional design methods. Indeed, the so-called "cognitive revolution" in psychology was more an elaboration of Thorndike's research program than a refutation of his behaviorism, substituting production rules for his "sarbons." Left intact were Thorndike's positivism, ${ }^{3}$ social nominalism, and epistemological assumptions. Evolutionary psychology, the supposedly new new thing, can in some ways be seen as a further turning back in cognitive psychology to its roots in Thorndike's biologically-based theories.

\section{Dewey's Treatment of Habit}

We have no record of a reply from Dewey to a letter from one of his regular correspondents ${ }^{4}$ imploring him to publicly "differentiate" his position from Thorndike's, though Dewey must have felt that he had already done so. In an early article published well before Animal Intelligence, Dewey (1972/1896) was sharply critical of psychological theories that reduced learning to elementary stimulus-response bonds. He wrote, "the reflex arc idea, . . . is defective in that it assumes sensory stimulus and motor response as distinct psychical existences, while in reality they are always inside a co-ordination and have their significance purely from the part played in maintaining or reconstructing the co-ordination" (p. 99). Dewey continued throughout his career to speak out against mechanistic and reductionist models of human cognition. Nowhere are these differences made more strikingly evident, however, than in the series of lectures he delivered at Stanford in 1918 and later published as Human Nature and Conduct (1988/1922). It is interesting to note that Dewey chose as a subtitle for this monograph, "An Introduction to Social Psychology," since it is Dewey's call for a social psychology in his 1916 APA address that served as the starting point for this paper. In Human Nature and Conduct, Dewey clarifies what he means by a 
"social psychology" and it bears little resemblance to Thorndike's extensions of his "connectionism" into the social sphere.

Like Thorndike, habits are primary for Dewey. His treatment of habit is different from Thorndike's in several ways, however. He (1988/1922) acknowledged that habits "are outgrowths of unlearned activities which are part of man's endowment at birth" (p. 65). Dewey argued that though instincts developmentally precede habits, which are acquired and social in nature, they are secondary in that they are not adequate to ensure the survival of the new born infant. It is the socially-structured habits of the surrounding adults that make sustained life possible. Dewey defined habits as "social functions," using the term function in its biological and mathematical senses. Habits, for Dewey, are functional in the same way that alimentation and respiration are functional. Habits also define a relationship involving the individual and its social and material environment. Habits derive from social custom and customs "are the pattern into which individual activities must weave themselves" (p. 54).

Habit dominates our day-to-day existence. As Dewey stated, "the more suavely efficient a habit the more unconsciously it operates" (p. 125). He went on, "Normally, the environment remains sufficiently in harmony with the body of organized activities to sustain most of them in active function" (p. 125). When habits come into conflict, however, or when someone or something enters the environment in such a way that practice becomes blocked, the individual seeks impulsively to restore the routine. ${ }^{5}$ Neither habit nor impulse are capable of finding a reasoned solution to the problem, however. For this, intelligence is required. Dewey wrote:

Yet habit does not, of itself, know, for it does not of itself stop to think, observe or remember. Neither does impulse of itself engage in reflection or contemplation. It just lets go. Habits by themselves are too organized, too insistent and determinate to need to indulge in inquiry or imagination. And impulses are too chaotic, tumultuous and confused to be able to know even if they wanted to. Habit as such is too definitely adapted to an environment to survey or analyze it, and impulse is too indeterminately related to the environment to be capable of reporting anything about it. Habit incorporates, enacts or overrides objects, but it doesn't know them. Impulse scatters and obliterates them with its restless stir. (p. 124)

In summary, conduct for Dewey is primarily habitual. When disrupted, however, conduct is comes under the control of impulse and intelligence. Intelligence provides a means to "adapt customs to conditions, and thereby remake them" (p. 54). Dewey's description of the ways in which impulse and intelligence oppose and animate each other is at times reminiscent of the writings of Freud. For Dewey, however, the struggle between impulse and intelligence is not deterministic - it is, indeed, the very basis of human freedom and, as a consequence, for moral responsibility.

Intelligence assists in the resolution of problematic situations through a process of inquiry.

Dewey (1991/1938) defined inquiry as "the controlled or directed transformation of an indeterminate situation into one that is so determinate in its constituent distinctions and relations as to convert the elements of the original situation into a unified whole" (p. 108). Dewey, in fact, believed that it is possible to develop habits for productive inquiry through extensive practice, just like any other kind of skill. The relationship between habit and inquiry, therefore, was a reflexive one-inquiry arises when habit is thwarted, but successful inquiry can lead to the development of new habits of inquiry. This, he argued, was the true purpose of education.

Dewey was sharply critical of Durkheim and "the French School" of sociology with its orientation to the structural features of society which provide the basis for social order. He objected to the reification of the social as something standing outside of and acting on the individual. Society influences the individual through habit and custom, but the individual also reproduces society in local action and has the capacity to reconstruct society in productive ways. Dewey, therefore, like Thorndike, viewed the social as an emergent property of interaction among individuals. They parted ways, however, with respect to how these local interactions were to be understood and theorized. 


\section{Rethinking the Learning Sciences Post-Thorndike}

Talcott Parsons, in his review of Thorndike's (1969/1940) Human Nature and the Social Order, suggested that Thorndike's work might have been better titled, "One Kind of Approach to the Scientific Study of Human Nature and Social Order" (quoted in G. Jonçich's introduction). Our problem is that this "one kind of approach" has become so thoroughly pervasive that it is difficult to find research in psychology and education today which has not been directly or indirectly shaped by Thorndike's ideas. As Lagemann (1989) wrote, "one cannot understand the history of education in the United States during the twentieth century unless one realizes that Edward L. Thorndike won and John Dewey lost" (p. 185). Standing, as we do, on the threshold of a new century, in this time of postpositivist rhetoric, perhaps it is time we reassess this contest.

Dewey's writings provide an alternative framework for understanding human behavior, learning, and social interaction. As we have seen, the psychologies of Thorndike and Dewey differed fundamentally in their treatment of habit. For Thorndike, it was habits all the way down-human behavior simply consists of chains of simple stimulusresponse associations. For Dewey, on the other hand, habit was but one component of a larger assembly comprising human conduct.

When Dewey called for a "social psychology" in his 1916 APA address, he was proclaiming the need for a new research agenda in psychology. He (1988/1922) warned that if practitioners of this new approach attempted "to render its facts in terms characteristic of old psychology" (p. 60), only confusion would result. Dewey (1988/1922) made clear that the social psychology he had in mind was a psychology of habit, one that "fix[es] its attention upon the objective conditions in which habits are formed and operate" (p. 61). Such a psychology would take a more molar approach to understanding behavior than the one upon which we currently base our researches. It would also be more pluralistic in that it would place the contributions of the various social sciences (e.g., philosophy, linguistics, sociology, history, or anthropology) on an equal footing with the findings of experimental psychology. Unfortunately, his call has so far gone unheeded.

In rethinking the foundations of our field today we must remember that Dewey continuously stressed that all inquiry is inherently tentative, contingent, and subject to further questioning and reanalysis. I offer his ideas, therefore, not as a new doctrine to replace that of Thorndike, but rather as a starting point from which we can begin to build a new future. For this purpose Dewey's writings are a rich source of inspiration. If Thorndike won out in shaping the research agenda for the last century, however, it is in no small part due to the fact that he provided in his own work a paradigm for those who followed. Dewey developed a more profound and better-elaborated model of human problem solving, but he was at best an armchair psychologist, leaving it to others to actually undertake the program of study. Determining how to do so stands as a grand challenge to this community as we enter the twentyfirst century.

\section{Endnotes}

(1) A derisive contraction of "S-R bonds" coined by McDougall, one of Thorndike's contemporaries and a critic of his connectionist theory (Jonçich, 1968).

(2) Should anyone doubt Lagemann's (1989) claim concerning the hegemony of Thorndike's theories in education today, one need look no further than the national obsession with standardized testing.

(3) Though as Bredo (personal communication) points out, cognitive science has adopted a more sophisticated form of logical positivism.

(4) Boyd A. Bode to John Dewey, 1927.01 .08 (05443), Center for Dewey Studies, Southern Illinois University, Carbondale, IL: Folioviews. [Original, John Dewey Papers 8/1, Special Collections Morris Library, Southern Illinois University at Carbondale.]

(5) See Koschmann, Kuutti, and Hickman (1998) for a discussion of the similarities between Dewey's arguments for the primacy of pre-reflective, habitual engagement in activity and Heidegger's development of being-in-theworld. 


\section{References}

Dewey, J. (1972/1896). The reflex arc concept in psychology. In J.A. Boydston (Ed.), John Dewey: The early works, 1882-1898, Vol. 5 (pp. 96-109). Carbondale, IL: Southern Illinois University Press. [Originally published as: Dewey, J. (1896). The reflex arc concept in psychology. Psychological Review, 3, 357-370.]

Dewey, J. (1985/1917). The need for social psychology. In J.A. Boydston (Ed.), John Dewey: The middle works, 1899-1924, Vol. 10 (pp. 53-63). Carbondale, IL: Southern Illinois University Press. [Originally published as: Dewey, J. (1917). The need for social psychology. Psychological Review, 24, 266-277.]

Dewey, J. (1988/1922). Human nature and conduct. In J.A. Boydston (Ed.), John Dewey; The middle works, 18991924, Vol. 14 (pp. 1-227). Carbondale, IL: Southern Illinois University Press. [Originally published as Dewey, J. (1922). Human nature and conduct. New York: Henry Holt \& Co.]

Dewey, J. (1991/1938). Logic: The theory of inquiry. In J. A. Boydston (Ed.), John Dewey: The later works, 1925-1953, Vol. 12. Carbondale, IL: SIU Press. [Originally published as Dewey, J. (1938). Logic: The theory of inquiry. New York: Henry Holt \& Co.]

Jonçich, G. (1968). The sane positivist: A biography of Edward L. Thorndike. Middletown, CN: Wesleyan University Press.

Koschmann, T., Kuutti, K., \& Hickman, L. (1998). The concept of breakdown in Heidegger, Leont'ev, and Dewey and its implications for education. Mind, Culture, and Activity, 5, 25-41.

Lagemann, E. C. (1989). The plural worlds of educational research. History of Education Quarterly, 29, $185-214$.

Sahakian, W. (1975). History and systems of psychology. NY: John Wiley \& Sons.

Thorndike, E.L. (1904). An introduction to the theory of mental and social measurements. NY: Teachers College.

Thorndike, E.L. (1911). Animal intelligence. NY: Macmillan.

Thorndike, E.L. (1913). Educational psychology. NY: Teachers College.

Thorndike, E.L. (1935). The psychology of wants, interests, and attitudes. NY: Appleton-Century.

Thorndike, E.L. (1969/1940). Human nature and the social order (Abridged and edited by G. Jonçich). Cambridge, MA: MIT Press. [Originally published as Thorndike, E.L. (1940). Human nature and the social order. NY: Macmillan.]

Thorndike, E.L. (1969/1943). Man and his works. Port Washington, NY: Kennikat Press. [Originally published as: Thorndike, E.L. (1943). Man and his works. Cambridge, MA: Harvard University Press.]

\section{Acknowledgments}

I would like to express my appreciation to the Center for Dewey Studies for the kind assistance I received while preparing this paper. Also, Eric Bredo and Gerry Stahl for their many helpful suggestions. 